Gazi University
Journal of Science
$\mathrm{http}: / /$ dergipark.gov.tr/gujs

\title{
Development of a Hybrid Radio Frequency Identification (RFID) and Biometric Based Library Management System
}

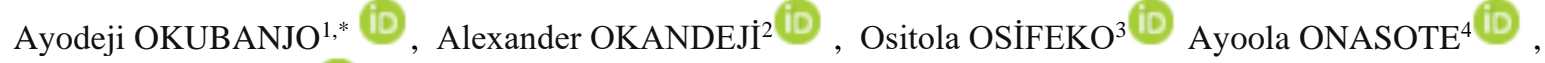 \\ Mufutau OLAYEMí ${ }^{5}$ \\ ${ }^{I}$ Olabisi Onabanjo University, Electrical and Electronics Eng. Dept., Ago-Iwoye, Nigeria \\ ${ }^{2}$ University of Lagos, Electrical and Electronics Eng. Dept., Akoka, Nigeria \\ ${ }^{3}$ Olabisi Onabanjo University, Computer Eng. Dept., Ago-Iwoye, Nigeria \\ ${ }^{4}$ Olabisi Onabanjo University, Library and Information Dept., Ago-Iwoye, Nigeria \\ ${ }^{5}$ Adegbenro ICT Polytechnic, Electrical and Electronics Eng. Dept., Itori, Nigeria
}

\section{Highlights}

- This paper focuses on the smart library management system.

- Integration of the LMS with biometric and RFID has been addressed.

- The challenges on the conventional method of LMS and security issues are presented.

- Integration of an LMS with internet-of-things, SMS, and email alert has been explained.

- The system performance evaluation based on the error rate has been discussed.

\section{Article Info}

Received: 01 Dec 2020 Accepted: 21 May 2021

\section{Keywords}

Radio frequency Identification

Biometric technology

Library management

system,

Authentication

\begin{abstract}
This paper presents a smart library management system based on the combination of RFID technology and the biometric recognition system to upgrade the performance of conventional library management. In particular, the proposed design combines a radio frequency identification (RFID) and Biometric technology to enhance user-processing time, improve user service, and curtail book theft, to ease updating of new books and further increase the biometric security of the system against an imposter. Using MySQL, the internet of things (IoT), and Java programming, we design a system that provides the user with unrestricted access to online library facilities with a personal computer or mobile devices. For improved efficiency, the proposed design integrated with SMS and an email alert notification system. The proposed design, thus allows the user to access books and course materials from a remote location in an authenticated and secured manner. The system performance was compared to the manual method in terms of book positioning function, false rejection rate, false acceptance rate, counting efficiency, average time spent on booking searching and the results show that the proposed system outperforms the conventional (manual) library system.
\end{abstract}

\section{INTRODUCTION}

Building an intelligent library to transform library operations such as registering, monitoring, tagging, tracking, security, and detecting users had attracted global concern. Collaboratively, the unprecedented global outbreak of coronavirus (COVID-19) has deprived millions of students the privileged to achieve dissemination of information and knowledge sharing [1]. The challenge with (manual) bibliographic records and filling of library books, articles, newspapers, magazines, monographs, etc., and users (students) registration in the Nigerian library, especially the higher institution of learning, calls for a rapid intervention of the digital revolution. Often time, book tagging, issuing, re-issuing and filing of books consume time and energy. Nevertheless, the library has been identified as one of the core structures of the University 
system with the sole responsibility of disseminating information and sharing knowledge for the students to keep them informed with trending research in their core areas of specialization.

It also serves as a research bedrock to unravel new ideas and a digital bank to store and share research outcome of the global digital network. Despite the vital roles of the library, it is not fully automated in Nigerian institutions of learning to meet the global standard. Sadly, the traditional method of book acquisition, cataloguing, circulation, issuing, and retrieval has been viewed as a norm in most Nigerian Universities. Consequently, retrieval and processing of books and user information become cumbersome and worrisome for both the patron and staff.

Interestingly, the Internet of Things (IoT) has facilitated cheap digital storage of information, high-speed data transmission via computer networks, clouds, and high-tech retrieval and processing of electronic document and information. These changes, especially, the rapid spread of the internet has restructured the feasibility and efficient distribution of the library management system. Therefore, there is a need to improve the existing method of library operation and management in Nigeria and also take into cognizance the issues of security and book theft that has become rampant in the library.

Recently, the use of, Radio Frequency Identification (RFID) has been adopted in health services- smart hospital, vehicle parking access control [2], insurance card, banks [3], passport, logistics, transportation [4] and staff control [5]. This has been further extended to the library as a form of a contactless wireless identification system [6] that serves as a substitute to the conventional identification system such as bibliographic records, bar code etc. The use of wireless radio frequency electromagnetic field technology [7] to identify, store, and track books has the core inherent of unitary identification, contactless proximity communication, information density, and a cheap cost of tags as advantages over other bar code systems $[2,8]$.

Generically, RFID is an electronic device that encodes digital information on an RFID tag and retrieves it through an RFID card reader through a radio wave. It has become a standardized technology and universal choice because it has overcome the limitation of line-of-sight access that is associated with bar codes used in most libraries, thus, it facilitates the fast issuing, re-issuing and identification of books within the shortest time and minimum energy. The adoption of RFID had received considerable interest in the library (as indicated in Table 1) over the past few decades and the quest for new development continues.

A hybrid RFID and Internet of Things (IoT) is proposed in [9]. RFID based Artificial Intelligence and wireless schemes are implemented in [10]. Authors in [11] examined the impact of the constructor on the use of RFID based system, and user satisfaction. 3D RFID based library search system is developed in [12]. Authors in [13] show that RFID technology is the future of library management. [14]improved the existing library system through the introduction of RFID technology and further improved self- service booking system. Data manipulation, impersonation, and unauthorized access to confidential information have been identified as the drawbacks of the conventional methods. In recent times, human unique, physiological or behavioural characteristics (known as biometric) such as fingerprints, face, iris, the contour of the hand, signature, and voice has been recognized as security measures against security threats[15-18].

Table 1. Application examples of RFID in the library

\begin{tabular}{|l|l|l|l|}
\hline Context and Application & Use of RFID & $\begin{array}{l}\text { Coupling with } \\
\text { other information } \\
\text { or communication } \\
\text { technologies }\end{array}$ & References \\
\hline $\begin{array}{l}\text { Attendance Monitoring of } \\
\text { students in the library }\end{array}$ & $\begin{array}{l}\text { Identification of } \\
\text { people }\end{array}$ & $\begin{array}{l}\text { Biometric finger } \\
\text { scanner, SMS }\end{array}$ & {$[19-21]$} \\
\hline Library Authentication & $\begin{array}{l}\text { Identification of } \\
\text { people and books }\end{array}$ & $\begin{array}{l}\text { Fingerprint } \\
\text { scanner }\end{array}$ & {$[22]$} \\
\hline $\begin{array}{l}\text { Intelligent book management } \\
\text { System }\end{array}$ & $\begin{array}{l}\text { Identification of } \\
\text { object, people and } \\
\text { books }\end{array}$ & RFID & {$[23]$} \\
\hline
\end{tabular}




\begin{tabular}{|l|l|l|l|}
\hline Book Security management & $\begin{array}{l}\text { Identification of } \\
\text { books }\end{array}$ & $\begin{array}{l}\text { Microsoft Visual } \\
\text { Studio and GSM } \\
\text { module for SMS }\end{array}$ & {$[24]$} \\
\hline Digitalized library & $\begin{array}{l}\text { Identification of } \\
\text { people and object }\end{array}$ & $\begin{array}{l}\text { Advanced } \\
\text { Encryption } \\
\text { Standard }\end{array}$ & {$[25]$} \\
\hline Book Tracking in libraries & $\begin{array}{l}\text { Identification of } \\
\text { books }\end{array}$ & $\begin{array}{l}\text { MYSQL Database, } \\
\text { MATLAB for GUI }\end{array}$ & {$[26,27]$} \\
\hline Asset Tracking in libraries & $\begin{array}{l}\text { Identification of } \\
\text { objects }\end{array}$ & Visual Studio & {$[28]$} \\
\hline $\begin{array}{l}\text { Intelligent Book search in } \\
\text { library }\end{array}$ & $\begin{array}{l}\text { Identification of } \\
\text { books }\end{array}$ & RFID and Wi-Fi & {$[6]$} \\
\hline $\begin{array}{l}\text { Connectivity between library } \\
\text { material and users }\end{array}$ & $\begin{array}{l}\text { Identification of } \\
\text { people and object }\end{array}$ & IoT Architecture & {$[29]$} \\
\hline $\begin{array}{l}\text { Library Service Management } \\
\text { System }\end{array}$ & $\begin{array}{l}\text { Identification of } \\
\text { books and people }\end{array}$ & $\begin{array}{l}\text { RFID, AI } \\
\text {,Wireless } \\
\text { Techniques }\end{array}$ & {$[10]$} \\
\hline $\begin{array}{l}\text { An Intelligent robot library } \\
\text { system }\end{array}$ & $\begin{array}{l}\text { Identification of an } \\
\text { object and books }\end{array}$ & $\begin{array}{l}\text { Robot Arm, Visual } \\
\text { Database }\end{array}$ & {$[30]$} \\
\hline
\end{tabular}

Several researchers have examined the issues of security breaches on biometric and suggested different countermeasure approaches to overcome this weakness. Attacked directed on the biometric templates on the database is regarded as the most potent attack on the biometric [31]. Besides, the possibilities of large feature similarities are another drawback of biometric and this undermined the uniqueness of the biometric trait. Then, a single biometric trait will not be appropriate for effective authentication. In contrast to existing results, this work aims to enhance the security of the library management system using a fused biometric and RFID system. In particular, this paper presents the development of a robust and efficient library management system that combines Radio Frequency Identification technology to improve the conventional method of book cataloguing and identification, biometric for user authentication, and the MYSQL database for a library management system.

\section{MATERIAL METHOD}

The library management system was designed to manage the process of retrieving and borrowing of books in the library as well as coordinating the process of users' identification and authentication. To achieve this, each book was uniquely identified via RFID tags attached to the module and communication was done wirelessly. An RFID sensor (the reader), MFRC522 was placed near the library desk to allow users access to reissue/issue/return depending on the actions required. Moreover, information regarding the book can be gained by both the authority and students remotely. The Library Management system (LMS) consists of RFID Reader (for Enrollment of user information), RFID tags, Finger-print scanner (for data verification), Arduino, I2C reader, 16 X 2 LCD, and USB connection to PC as shown in Figure 1. Each RFID tag has a unique ID or serial number that has been assigned to each student during library registration. Student access to the library is strictly based on the RFID card.

A 5V direct current, voltage source is supplied to power the RFID (I2C) reader and the transmit pin of the Arduino ATmega168. The Arduino Uno is programmed with a $\mathrm{C}+$ programming language and the 16X2 liquid crystal display (LCD) is used to display the initialization stage of the RFID system which notifies the user on the readiness to initiate tag swapping. The database is developed with Java programming coupled with a library rule to enhance the functionality of the library. The LMS servers are primarily developed based on the book information and can as well interact with, and manage information from an RFID reader, self-help borrowing platforms handling the user premises equipment and other relevant devices through Wi-Fi. 


\subsection{Enrolment Stage}

User data (user ID, card ID, surname, other names, phone number, department, faculty, campus address, number of books) and biometric data (fingerprint data) are provided by the user at this stage. This stage is also known as the registration stage where vital information of the library users is registered through a graphical user interface (GUI) as depicted in Figure 2. The enrollment stage of the system was grouped into data sensing module, feature extraction module, encryption module and template database for unified data flow, and easy error correction. A unique identification number (ID) was created for each subject coupled with the biometric data, RFID tag, and it is unique across all subjects. Furthermore, a data sensing module include a fingerprint capturing unit for detecting and capture the user's raw data. It uses high-quality image digital persona 4500 biometric scanners. Also, the module is connected to the microcontroller Arduino Uno via physical pins. The Arduino Uno serves as a processing unit that is coded to perform fingerprint enrollment, image matching, feature extraction, identification and authentication of users and books. To further strengthen the security of the developed system, a webcam is incorporated into the design to capture user image automatically. The webcam is automated in a way to capture only the subject facing the rear camera to permit image uniformity and high-quality image during enrollment and authentication processes.

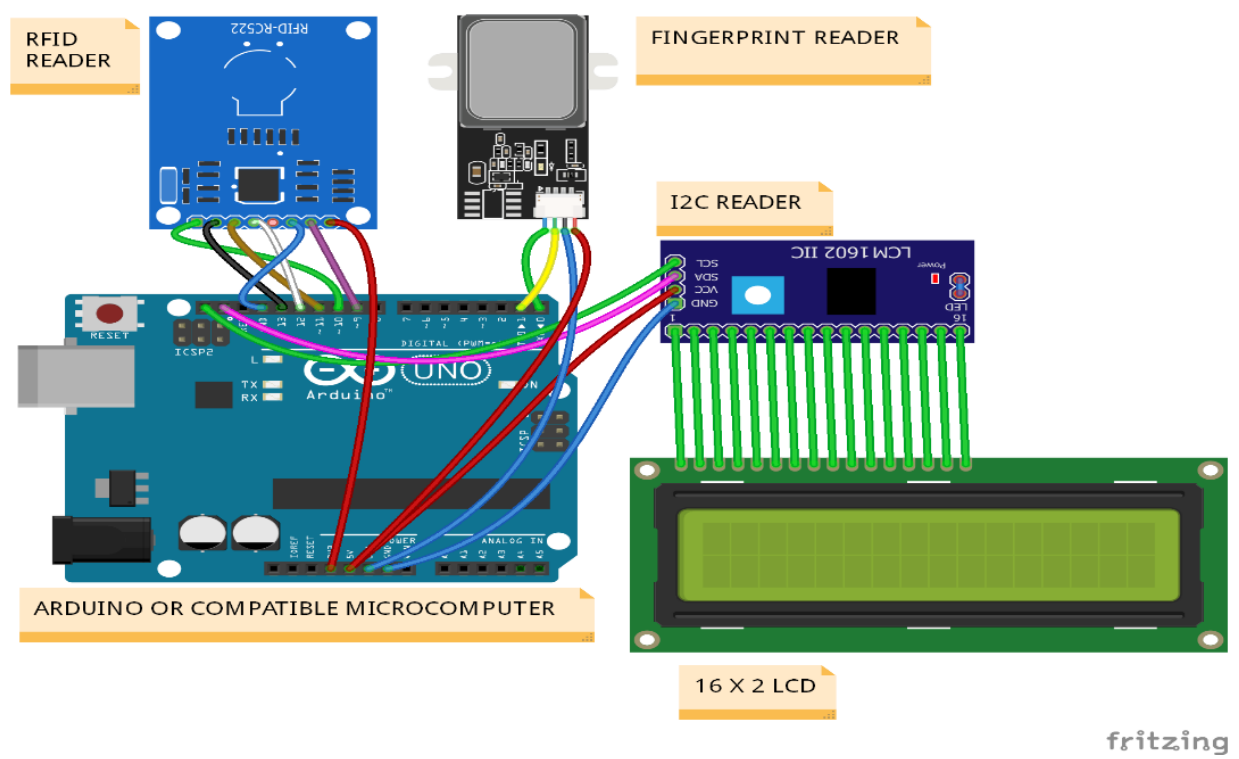

Figure 1. RFID module 


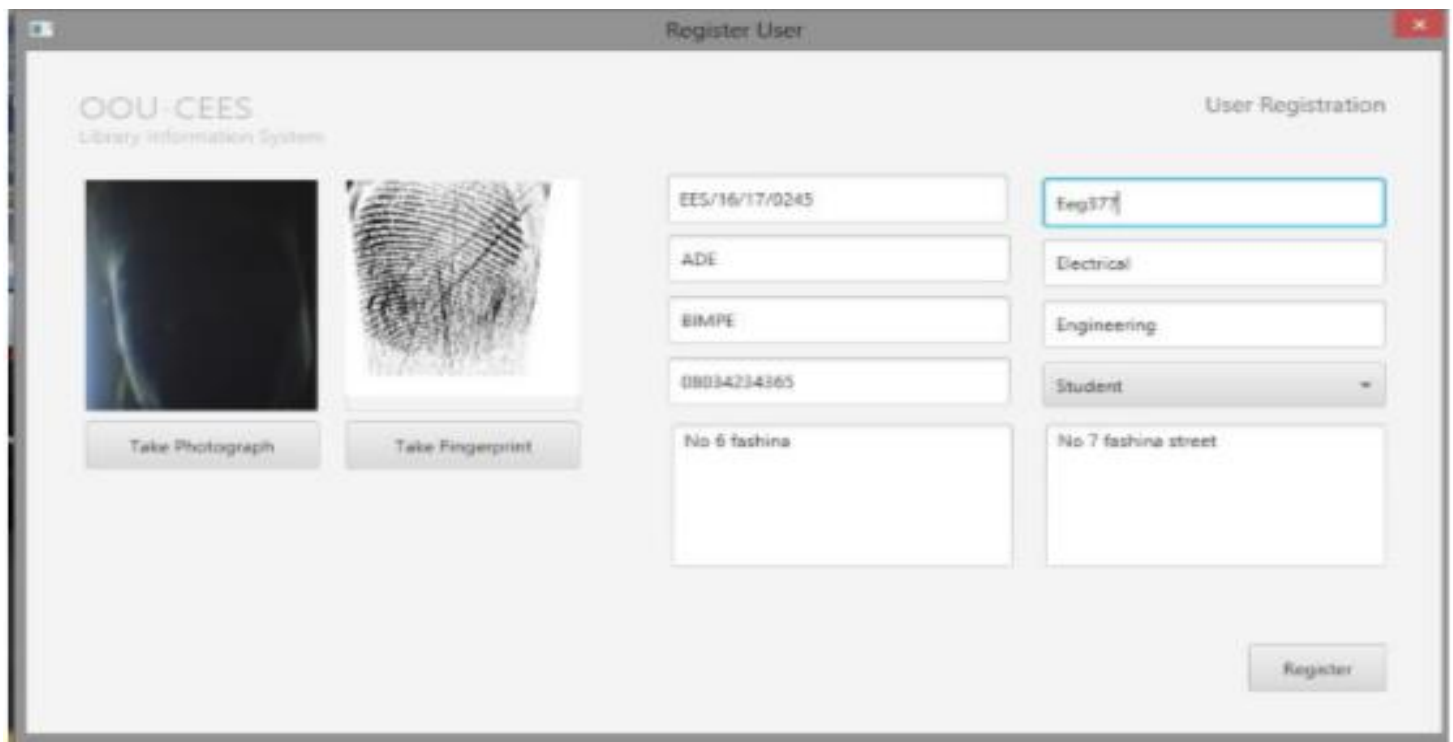

Figure 2. Registration interface

To detect a facial image, the face scanner was developed based on AdaBoost object detection algorithm. The algorithm involves training a collection of increasingly discriminating weak classifiers and then combined them to produce a strong classifier. This stage also involves image matching where user images are evaluated and scanned through the image library templates in the database to match the true identity of the images against the stored image templates. Figure 3 shows the system user interface including face and fingerprint interfaces. The fingerprint scanner communicates with the Arduino Uno via UART interface, PC, and laptop over USB.

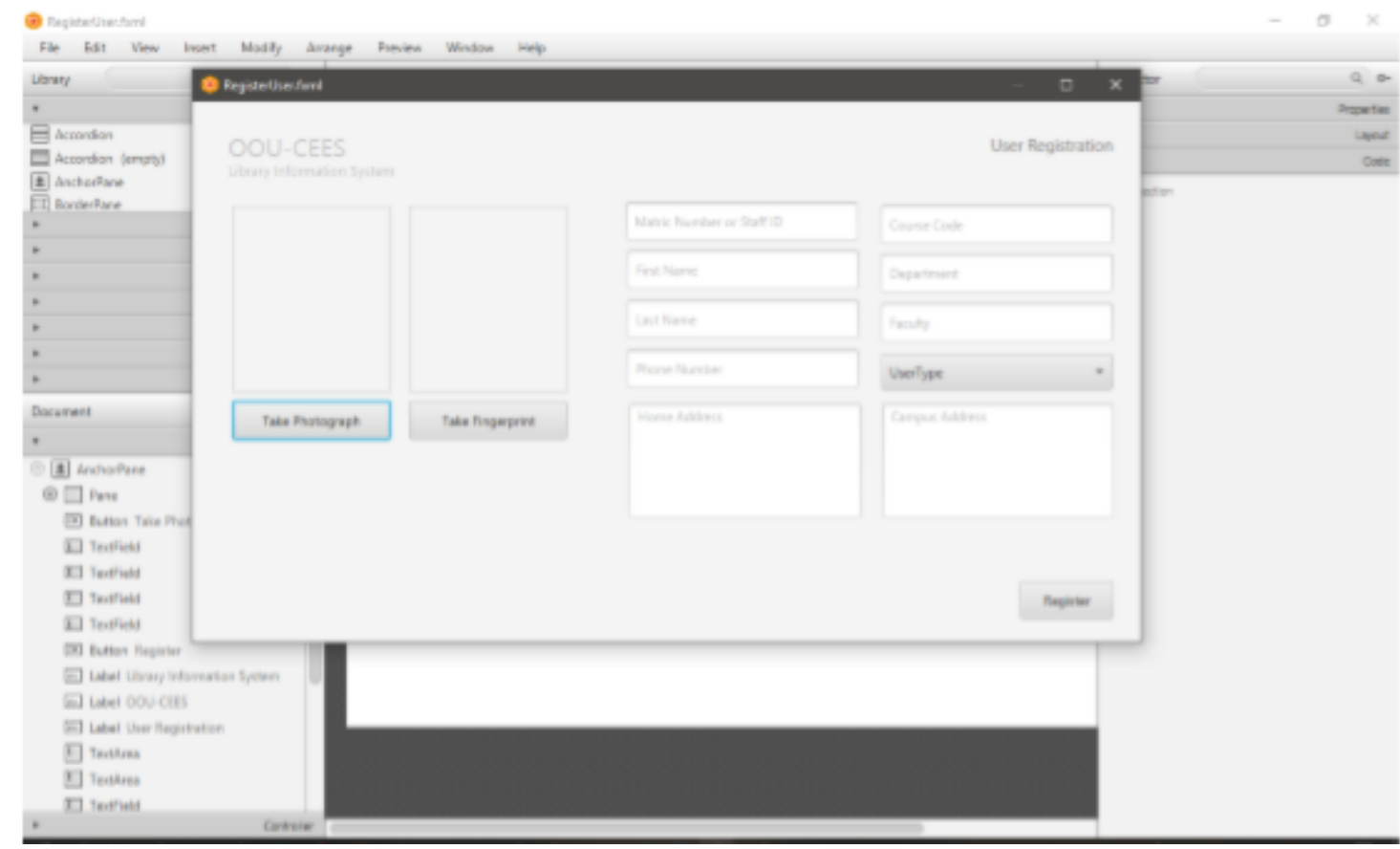

Figure 3. Biometric capturing interface 


\subsection{Authentication Stage}

At this stage, the subject presents the RFID card which is swiped on the RFID reader as shown in Figure 5 to access to the database management system. Thereafter, the subject finger is placed on the biometric scanner for scanning and the subject facial image is automatically captured for further identification of the user enrollment status with the stored templates in the database. If the acquired biometric traits matched the finger and facial library templates the developed system pop-up the user identity in the user interface. Also, several processes are involved in the authentication stage such as the registration unit, the feature extraction unit that uses an algorithm to extract the image, the matching unit which compares the acquired biometric templates during the enrollment stage with a stored template, and decision unit which decides the degree of similarity based on the matched score. The matched score may be affected by the quality of the specified biometric data. The matching unit made a logic AND gate to authenticate the claimed identity.

The system matches fingerprints, upon approval, it proceeds to match the faces, and else it denies the subject. A subject is only granted access if both the fingerprints and facial image match the stored templates in the database. Hence, once the user identity has been verified and the system confirms the user identity, the user would be authorized to access the library system. The users can lend, borrow, check the available books, borrowed remotely, check the expiration time, etc. Figure 4 shows the Authentication interface for the users to make choices and decision regarding the available books. Furthermore, if the desired books, articles or journals have been borrowed, the users can also be notified the borrowers' identity, and when the book would be returned. Thus, a message is sent to the user through a global system for mobile communications (GSM) module, and an email address to notify the user of the expiration date of the borrowed book as well as the charges placed on unreturned books. A Wi-Fi communication module is embedded into the library management system to enable the user to access the database remotely anywhere in the world provided there is internet connectivity.

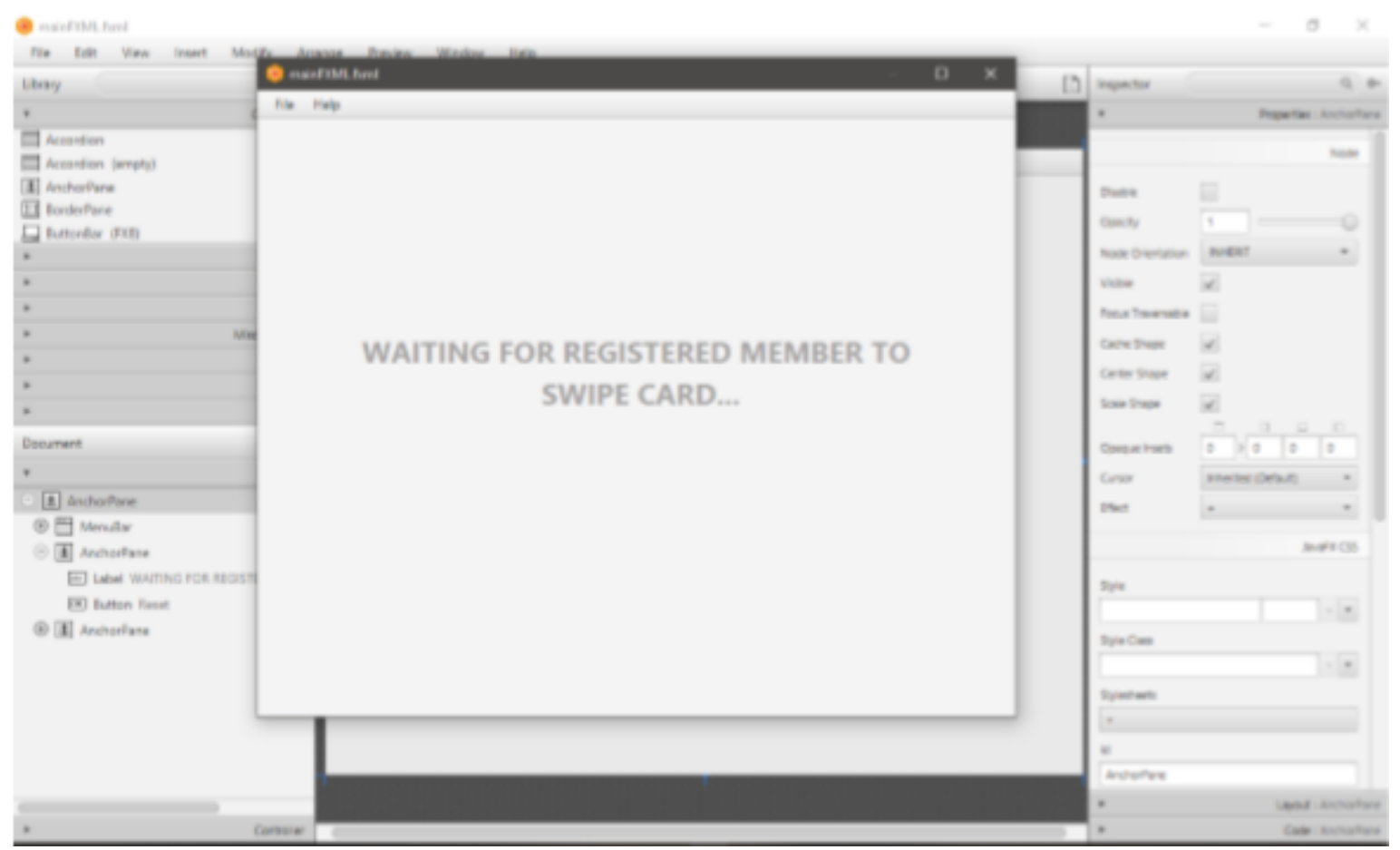

Figure 4. RFID interface 


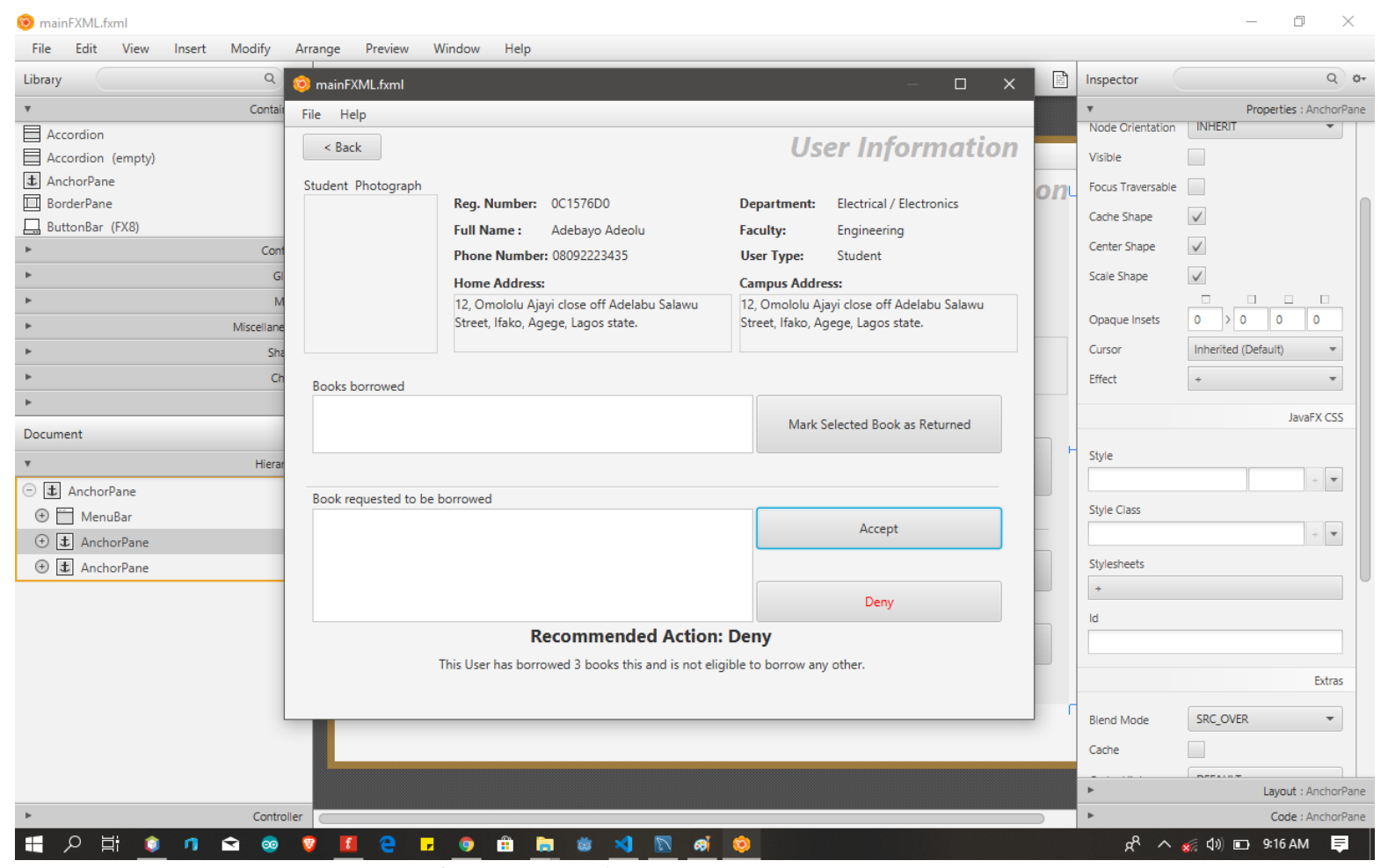

Figure 5. Authentication interface

\subsection{Developed System Algorithms}

The developed system's step-by-step algorithms are as follows:

Step 1: Ask user to swipe card

Step 2: Swipe card

Step 3: Is the card UID exist in the Database? If yes go to Step 5 otherwise go to Step 4

Step 4: Open Registration page and register and go to Step 1.

Step 5: Show place fingerprint on a fingerprint sensor and read a fingerprint

Step 6 Does the fingerprint match a fingerprint in the database? If yes, go to Step 8, otherwise, go to Step 7.

Step 7: Request another attempt from the user, and then return to Step 1.

Step 8: Display the user information page and enter the title of the book to be borrowed.

Step 9: Can the user borrow a book? If yes, go to Step 11; otherwise, go to Step 10.

Step 10: Ask the user to return previously borrowed books and go to Step 1.

Step 11: Borrow books for the user, save borrowed books to the database, and notify the user of the library's terms and conditions on borrowed books via email and SMS.

Step 12: provide a link for the user to access the library's online service and end the process

\section{LIBRARY USAGE RULES AND POLICIES}

A clear understanding of the library rules and policies will enhance users' knowledge of the library, and also reduce the stress of the librarian and other associated staff. Hence, well-detailed library rules and policies were developed in a simple and clear language as follows:

- The library manages books and users, i.e. books are available in the library for the user to read or borrow

- A book must have an author and must fall under a category. A category is a group of books with similar information. 
- A book must have status; it is either borrow-able or not borrow-able.

- An author may write several books.

- A user is a person who had registered with the library.

- A user must have an RFID card (Library ID) to access the library facility.

- A user can either be a staff or a student.

- A user must have the privilege; it is either lendable or not lendable.

- A student user has a duration of expiration.

- Student user may borrow 2 books at a time for two weeks.

- A staff user has status; it is either active or retired.

- Staff user may borrow 3 books at a time for a four weeks.

\subsection{Database Implementation}

The database designed with MYSQL, an open-source SQL relational management system coupled with Java programming language to develop a web-based library management system. Through investigation on the library functionality, the following entity types; Book information entity, Authors information entity, category information entity (Figure 6), and users' information entity, and identifiers also suggested for each entity together with selected important attributes. The book information entity records vital information about the book that uniquely distinguishes the entity in the database such information are ISBN, book ID, library ID, title, edition, authors, the country of publication, copyright year, borrowed status, borrowed issue date, borrowed by etc.

On the other hand, the author's information entity contains information that reveals the identity of the author and other vital details such as author ID, first name, last name and country. In contrast, the user information entity encompasses users' personal information and borrowing status, which consists of user ID, card ID, registration No., the surname, other names, phone number, email, Department, user type, photograph details, fingerprint details, home address and faculty amongst others. The category information entity, on the other hand, primarily used to restrict the borrowing ability of the user types. This includes category ID, category name etc.

\subsection{Logic Structured Design}

The Entity Relational (E-R) diagram is further simplified and turn into Entity Relational Model (ERM) to prevent the database chaos and to enhance users' usability. The library is a collection of diverse books. These books are classified into several categories. The identifier for a book is Book_ISBN, while the identifier for a category is Book_Category ID. The additional attributes of the book are; Title, Copy_Right_Year, Country_of_publication, Total_Copy, Borrowed_Copy, Edition, and Category. A category may group any number of books. Each book must belong to exactly one category. Another attribute of the category is Category_Name. A book must have an author. The identifier for an author is Author_ID and other attributes are First_Name, Last_Name, and Country.

An author may write several books but must have written at least one book. The library registers individuals. An individual becomes a user after registering with the library. The identifier for the user is User_ID. Other attributes for the user are RFID_Card_ID, Surname, Other_Name, Mobile_Phone, Registration_No, Department, Home_Address, Campus_Address, Number_of_Books_Borrowed, Privilege, and User_Type. The library gives access to users based on privilege. An identifier for the privilege is Privilege_ID, the other attribute for the privilege is Privilege_Name. The library has devised a means for grouping users. Users are sub-divided into two namely; Student user and the Staff user. Student user has a duration of expiration while the Staff user is a permanent user. The Staff user is identified by Employee_ID.

The Staff user has employee status. The identifier for Employee status is Status_ID. Another attribute for identifier for Student User is Student_ID. Other important attributes of Student User are_Matriculation No, Year_of_Entry, Course_of_study and Department. Users borrow books. Borrowed is an associative entity. The identifier for borrowed is Borrow_ID. Other attributes are Borrowed_Issued_Date, and 
Borrowed_Due_Date. A borrowed book can only be assigned one status at a time; it is either returned or awaiting. Borrowed Status is identified by Status_ID and additional attributes are Status_Name and Book_RFID_Tag_No.

$\square$ users
user_id INT(11)
card_uid V ARCHAR(255)
registration_number VARCHAR (255)
surname VARCHAR(255)
other_nam e VARCHAR(255)
phone_number VARCHAR(255)
departm ent VAROHAR(255)
faculty VARCHAR(255)
home_address VARCHAR(255)
campus_address VARCHAR(255)
no_of_books_borrowed VARCHAR(255)
user_type VARCHAR(255)
photograph_location VARCHAR(255)
fingerprintlocation VARCHAR(255)
Indexes

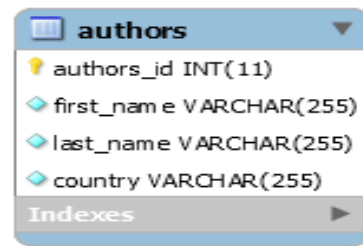

$\square$ books
book_id INT(11)
library_id VARCHAR(255)
title VARCHAR(255)
isbn VARCHAR(255)
edition VARCHAR(255)
authors_id VARCHAR(255)
county_published VARCHAR(255)
copy_right_year VARCHAR(255)
borrowed_status VARCHAR(255)
borrowed_issue_date VARCHAR(255)
borrowed_due_date VARCHAR(255)
borrowed_by VARCHAR(255)
Indexes

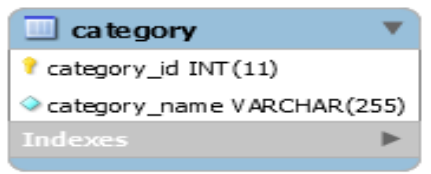

Figure 6. Entity Relational (E-R) diagram

\subsection{The Realization of Database}

The database structured in a systematic order to reflect all the entities that make up the data model in the Library management database system. The following entities such as author information, book information, user information, and category information are shown in Tables 2, 3, 4 and 5, respectively.

Table 2. Author entity

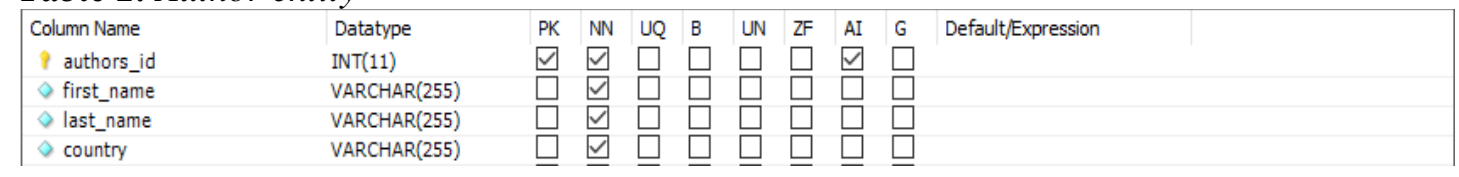

Table 3. Book entity

\begin{tabular}{|c|c|c|c|c|c|c|c|c|c|c|}
\hline Column Name & Datatype & PK & $\mathrm{NN}$ & UQ & B & UN & $\mathrm{ZF}$ & AI & G & Default/Expression \\
\hline$?$ book_id & INT(11) & $\nabla$ & $\nabla$ & $\square$ & $\square$ & $\square$ & $\square$ & $\square$ & $\square$ & \\
\hline library_id & VARCHAR(255) & $\square$ & $\square$ & $\square$ & $\square$ & $\square$ & $\square$ & $\square$ & $\square$ & \\
\hline title & VARCHAR(255) & $\square$ & $\sqrt{\square}$ & $\square$ & $\square$ & $\square$ & $\square$ & $\square$ & $\square$ & \\
\hline isbn & VARCHAR(255) & $\square$ & 可 & $\square$ & $\square$ & $\square$ & $\square$ & $\square$ & $\square$ & \\
\hline edition & VARCHAR(255) & $\square$ & $\square$ & $\square$ & $\square$ & $\square$ & $\square$ & $\square$ & $\square$ & \\
\hline$\Delta$ authors_id & VARCHAR(255) & $\square$ & $\bar{\nabla}$ & $\square$ & $\square$ & $\square$ & $\square$ & $\square$ & $\square$ & \\
\hline county_published & VARCHAR(255) & $\square$ & $\bar{\nabla}$ & $\square$ & $\square$ & $\square$ & $\square$ & $\square$ & $\square$ & \\
\hline copy_right_year & VARCHAR(255) & $\square$ & $\bar{\nabla}$ & $\square$ & $\square$ & $\square$ & $\square$ & $\square$ & $\square$ & \\
\hline borrowed_status & VARCHAR(255) & $\square$ & 可 & $\square$ & $\square$ & $\square$ & $\square$ & $\square$ & $\square$ & \\
\hline borrowed_issue_date & VARCHAR(255) & $\square$ & $\bar{\nabla}$ & $\square$ & $\square$ & $\square$ & $\square$ & $\square$ & $\square$ & \\
\hline borrowed_due_date & VARCHAR(255) & $\square$ & $\square$ & $\square$ & $\square$ & $\square$ & $\square$ & $\square$ & $\square$ & \\
\hline borrowed_by & VARCHAR(255) & $\square$ & $\nabla$ & $\square$ & $\square$ & $\square$ & $\square$ & $\square$ & $\square$ & \\
\hline
\end{tabular}


Table 4. User entity

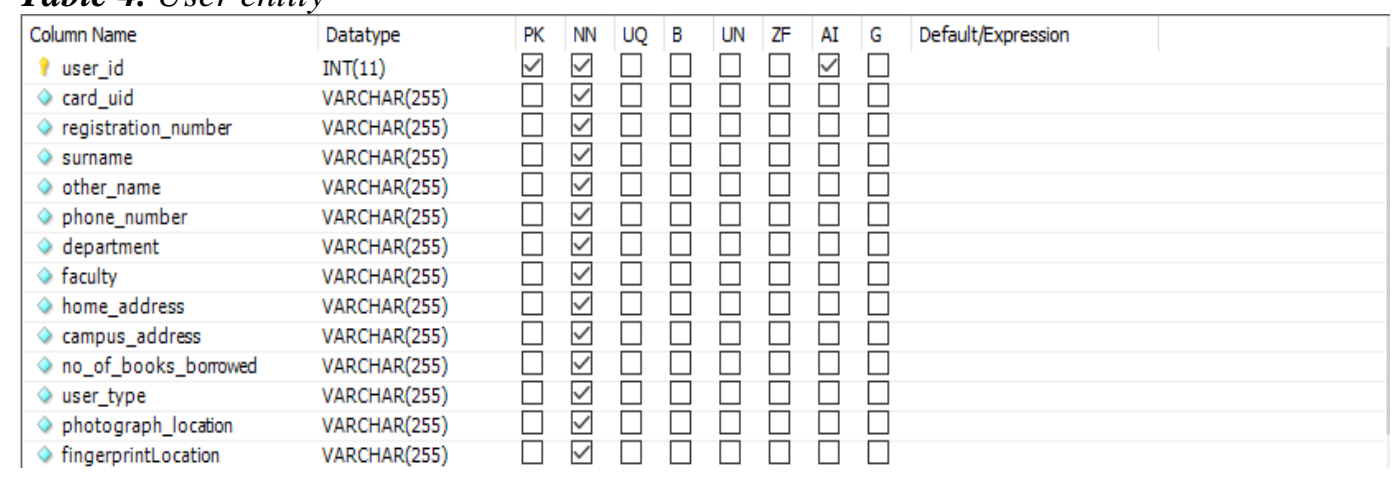

Tabel 5. Category entity

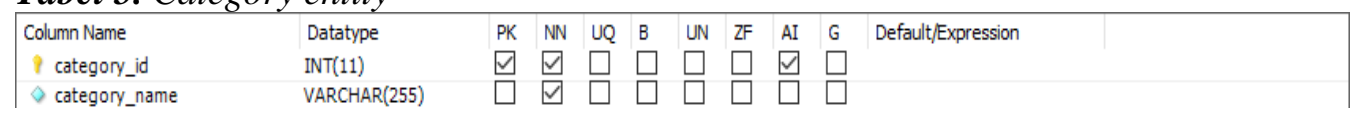

\subsection{Performance Evaluation}

Assessment of biometric system accuracy relies on the effectiveness of performance metrics. These metrics attempt to identify the mechanism's sensitivity in distinguishing between genuine users and imposters. Over time, variability in biometric features sets poses serious challenges for biometric systems to genuinely identify genuine users from imposters or vice versa. Previous research [32-35] on biometric systems has used performance indices such as the False Acceptance Rate (FAR), False Rejection Rate (FRR), and Equal Error Rate (EER) to evaluate the performance of biometric mechanisms. FAR and FRR, on the other hand, are evaluated by varying the score threshold to the similarity score. Furthermore, the Detection Error Tradeoff (DET) and Receiver Operating Characteristics (ROC) are two popular methods for plotting performance evaluation results (ROC). The EER value is the point at which the FAR and FRR are equal, as determined by tracing ROC-based curves for the FAR and FRR. EER is a quick way to compare two systems, and a low ERR indicates that a system is efficient.

Let $(\mathrm{T}, \mathrm{W})$ be a similarity score indicating how similar the "input" query features $\mathrm{W}$ are to the "stored" template features $\mathrm{T}$. The matched result is a value between zero and one. The closer the score is to one, the closer the match between the template and the query. To make a matching decision, the system establishes a threshold such that,

$$
\left\{\begin{array}{l}
\operatorname{Score}(T, W) \geq \lambda \Rightarrow \text { TandWmatch }(T \equiv W) \\
\operatorname{Score}(T, W \prec \lambda) \Rightarrow \text { TandWunmatch }(T \neq W)
\end{array} \cdot\right.
$$

A biometric system's matching error can essentially be divided into two categories:

1. The false rejection error corresponds to the denial of genuine users who are imposters. The false rejection rate is defined as the expected probability that the two samples $\mathrm{T}, \mathrm{W}$ acquired from the same subject are declared as a "non-match" (FRR).

2. A false acceptance error occurs when an imposter is accepted as a legitimate user. The false acceptance rate is defined as the expected probability that two samples of the same biometric features originating from various users will be erroneously declared as "match" (FAR)

The FRR and FAR threshold dependent. Decreasing the value of this threshold makes the system more tolerant of some genuine users' intra-variations and noise, so decrementing FRR results in increasing FRR. On the other hand, if the threshold is raised to exclude some minor inter-user variations and thus to secure 
the system with a low FAR, the FRR rises. As a result, lowering FAR and FRR is impractical, and tradeoffs must always be made to ensure that the parameters are tailored for particular applications.

\section{THE RESEARCH FINDINGS AND DISCUSSION}

The RFID and Biometric based (smart) library management system is divided into five different catalogue section namely; Electrical Engineering (EE), Computer Engineering (CE), Civil Engineering (CE), Mechanical Engineering (ME), and Agricultural Engineering (AE) with their corresponding book profile from the period of 2009 to 2018 as shown in Figure 7.

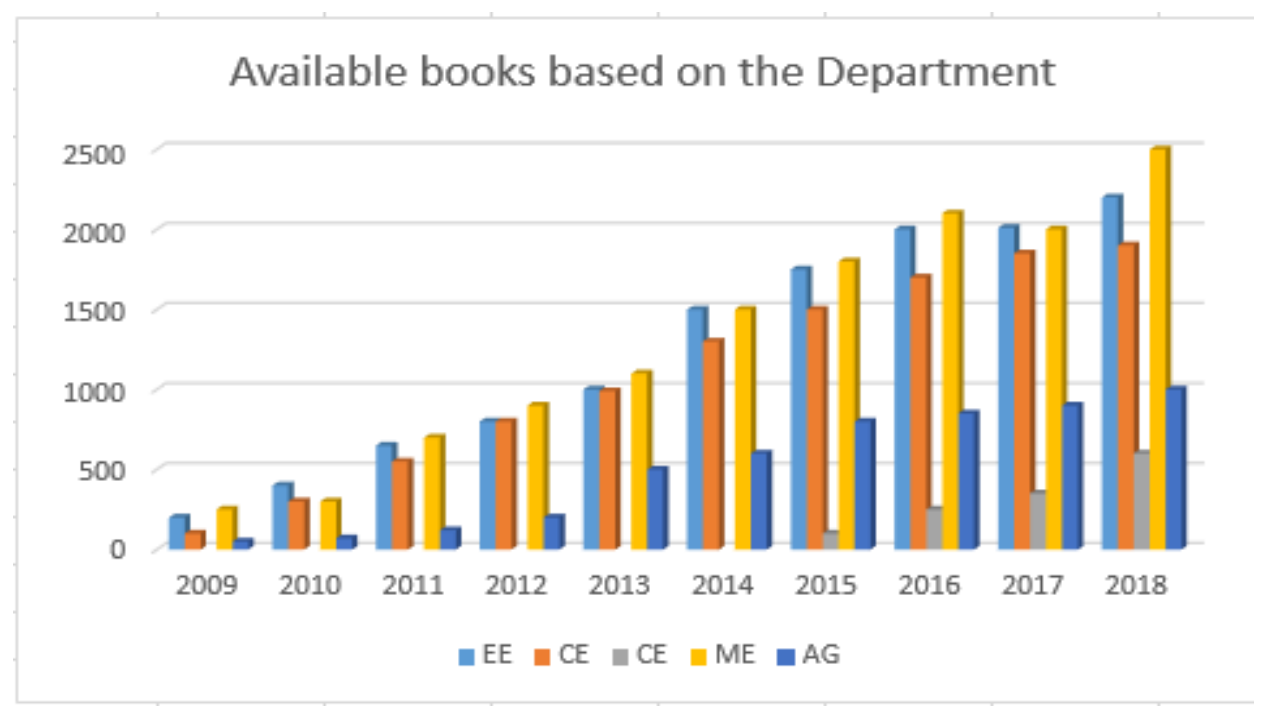

Figure 7. Catalogue section of five departments

The performance of the conventional (manual), and RFID and biometric-based (smart) library management systems were tested based on the book counting (to estimate total time spent and manpower required), book positioning and book pick up time. To ascertain that a reliable and dependable data were obtained, questionnaires were administered to 500 students to determine the most effective and efficient method as regards to manual and smart LMS. Also, the performance evaluation of the fingerprint scanner to identify and authenticate the rightful subject based on false-rejection error rate (FRR) and false-acceptance error rate (FAR) was carried out on the biometric device.

The percentage of occurrence of all verification attempt is regarded as the error rate while an attempt describes one round of a person using the system to verify a registered subject. The LMS based on three trials. Therefore, the false-rejection is known as a denial of a subject with identity during an attempt, while false- acceptance is the approval of an imposter as a subject. To evaluate the false rejection rate, the test examined at varying threshold values.

Figure 8 shows the graph of the false rejection rate at the varying threshold value for one-trial, two-trial, and three-trial configurations, respectively. It can be deduced from Figure 8 that, for the authentication system, the false rejection rate error decreases as the threshold decreases. The system is further subjected to a false acceptance test to ensure that the accuracy of the biometric devices in identifying the authentication of imposters who are incorrectly accepted. Figure 9 shows the false acceptance rate over the threshold value of $1.5 \%, 2.0 \%$, and $2.20 \%$ for one, two, and three- trials, respectively, for the subjects that deceptively accepted. It is also germane to note that the probability of an imposter user to be accepted decreases as threshold increases as indicated in the same graph.

It is obvious from Figure 10 that it took 8 staff, 10 hours to check all the book based on conventional (manual) library management system while it took only one staff, one minute to take the inventory of the book in RFID and Biometric based- smart library management system. Hence, the smart LMS is more 
efficient and superior to the manual method due to the advantage of contactless wireless communication of the tags and reader technology. Furthermore, Table 6 shows the comparison between the manual and smart book position in the library. It is obvious that after one week of library operations, about 300 Engineering books were wrongly positioned, misplaced and some of the books were completely unrecognizable in the manual LMS because of flaws during manual sorting, and administrator's imperfections.

The average time spent by the Department users was also compared with both library management systems as shown in Figure 11. It can be inferred from the plot that users spent longer hours in searching for books using the conventional library system than the smart LMS. It took EE users, CE users, CI users, ME users, and $\mathrm{AE}$ users about 10mins, $18 \mathrm{mins}, 10 \mathrm{mins}, 20 \mathrm{mins}$, and $5 \mathrm{mins}$, respectively, compared to 1 minute spent for all users in the smart library management system. Accordingly, smart LMS is time-efficient. Table 9 provides a summary of the system functionality, while Table 7 compares the performance of hybrid systems to standalone FRID and biometric library management systems. Figure 12 depicts the overall system design.

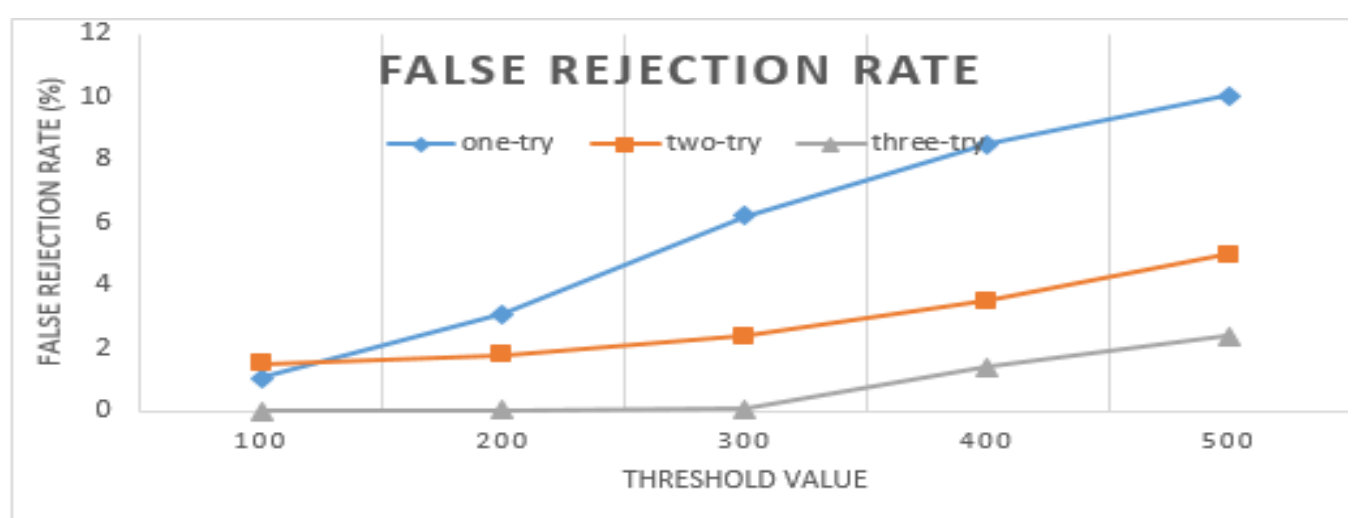

Figure 8. False-Rejection Rate for FRID-biometric based LMS

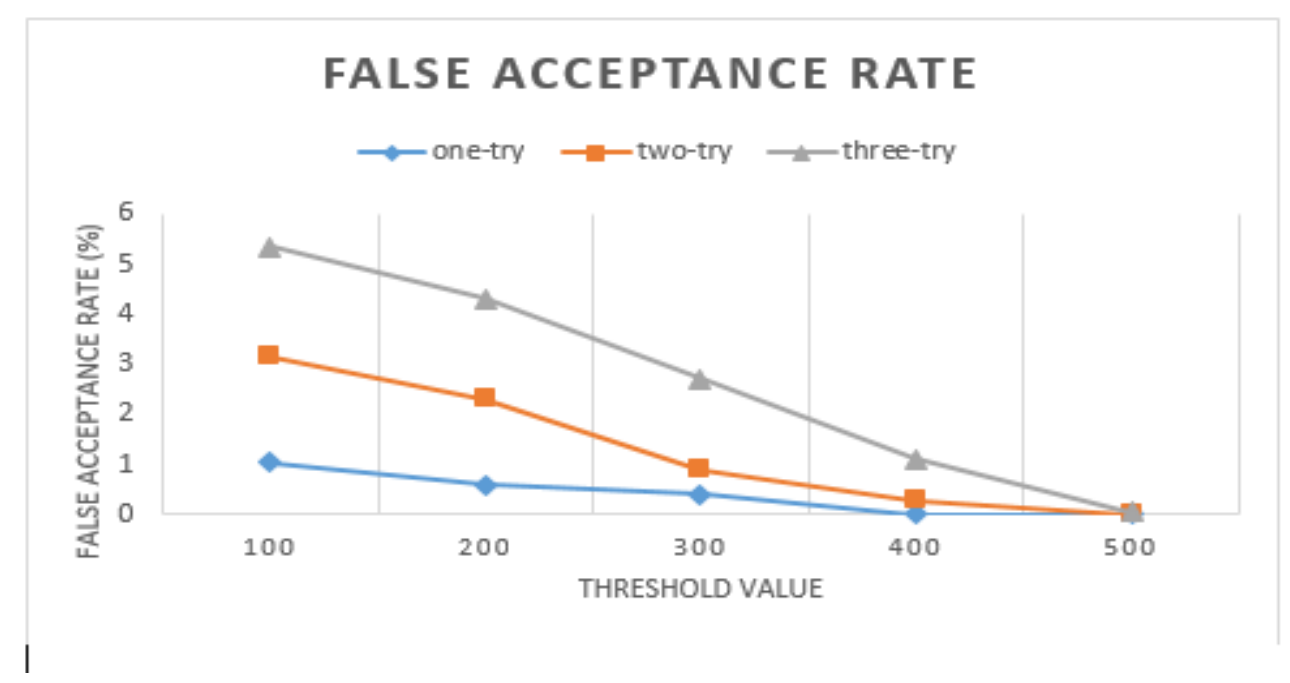

Figure 9. False-Acceptance Rate for FRID-biometric based LMS 


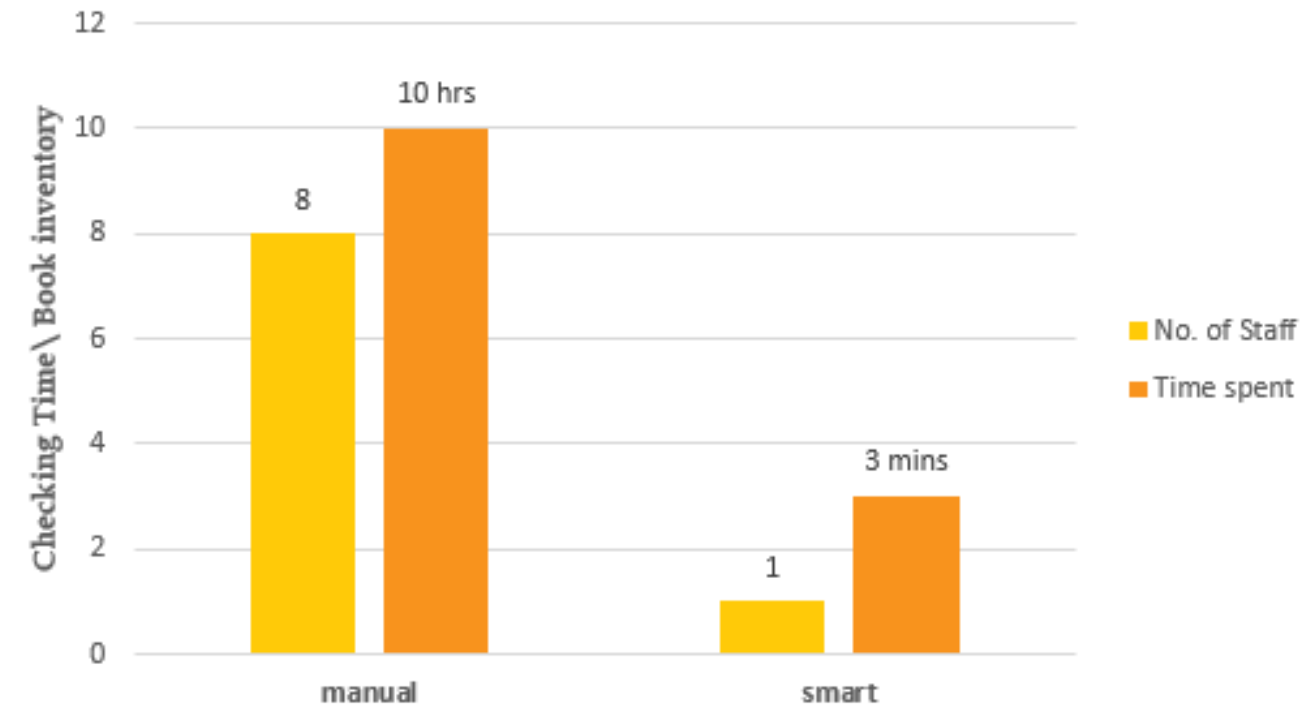

Figure 10. The Comparison of counting efficiency of manual and smart LMS

$$
25
$$

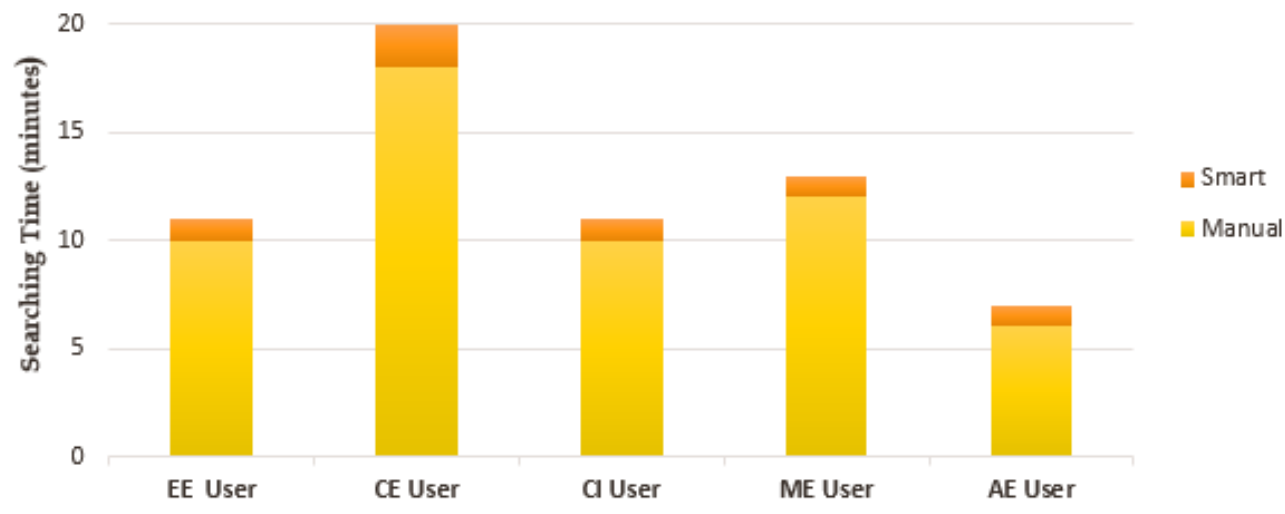

Figure 11. An Average Time spent in searching for a book by Users 
Table 6. Functionality comparison of the library management system

\begin{tabular}{|l|l|l|l|l|l|}
\hline $\begin{array}{l}\text { LMS } \\
\text { Type }\end{array}$ & Inventory & Tagging & Barrier System & $\begin{array}{l}\text { Anti-theft } \\
\text { Detection } \\
\text { System }\end{array}$ & $\begin{array}{l}\text { Registration } \\
\text { of Users }\end{array}$ \\
\hline Manual & Manually & Manually & Staff on duty & None & Smanually \\
\hline Smart & Smart & Smart RFID & Smart & $\begin{array}{l}\text { Snline / } \\
\text { Automated }\end{array}$ \\
\hline $\begin{array}{l}\text { LMS } \\
\text { Type }\end{array}$ & Self-check & $\begin{array}{l}\text { SMS/ e-mail } \\
\text { Alert }\end{array}$ & Book Searching & $\begin{array}{l}\text { Monitoring of } \\
\text { books }\end{array}$ & $\begin{array}{l}\text { Image } \\
\text { capturing }\end{array}$ \\
\hline Manual & Staff & None & Manually & Staff & $\begin{array}{l}\text { Passport } \\
\text { photograph }\end{array}$ \\
\hline Smart & RFID & Available & $\begin{array}{l}\text { Database } \\
\text { Searching }\end{array}$ & RFID & $\begin{array}{l}\text { Image } \\
\text { Capturing }\end{array}$ \\
\hline $\begin{array}{l}\text { LMS } \\
\text { Type }\end{array}$ & $\begin{array}{l}\text { Biometric } \\
\text { Security }\end{array}$ & Verification & Authentication & $\begin{array}{l}\text { Return and } \\
\text { Renewal } \\
\text { services }\end{array}$ & $\begin{array}{l}\text { Web-based } \\
\text { Application }\end{array}$ \\
\hline Manual & None & Staff & Staff & $\begin{array}{l}\text { Manually and } \\
\text { Letter to the } \\
\text { user through the } \\
\text { Department }\end{array}$ & None \\
\hline Smart & $\begin{array}{l}\text { Fingerprint } \\
\text { scanner }\end{array}$ & Smart RFID & Smart RFID & $\begin{array}{l}\text { Text message } \\
\text { and Email Alert }\end{array}$ & $\begin{array}{l}\text { Through Wi- } \\
\text { Fi and IoT }\end{array}$ \\
\hline
\end{tabular}

Table 7. Performance Comparison of hybrid systems to standalone FRID and biometric library management systems

\begin{tabular}{|c|c|c|c|}
\hline Performance Metrics & $\begin{array}{ll}\begin{array}{l}\text { Standalone } \\
\text { system }\end{array} & \text { FRID } \\
\end{array}$ & $\begin{array}{l}\text { Standalone } \\
\text { Biometric System }\end{array}$ & Hybrid System \\
\hline $\begin{array}{l}\text { Data Acquistion } \\
\text { (Integrity, } \\
\text { Confidentiality): } \\
-\quad \text { Personal data } \\
-\quad \text { Tag information } \\
-\quad \text { Biometric data } \\
-\quad \text { Books data }\end{array}$ & $\begin{array}{l}\text { Efficient but lack } \\
\text { provosion for } \\
\text { biometric information }\end{array}$ & $\begin{array}{l}\text { Efficient but lack } \\
\text { information on tag } \\
\text { information }\end{array}$ & $\begin{array}{ll}- & \text { Very effective } \\
\text { - } & \text { Provides a dual mode of } \\
\text { data collection' } \\
\text { - } & \text { Secure algorithms are } \\
\text { used for user data } \\
\text { verification and } \\
\text { authentication. }\end{array}$ \\
\hline $\begin{array}{cl}\text { Costs } & \\
- & \text { Components } \\
- & \text { Arduino } \\
- & \text { Biometric Scanners } \\
- & \text { FRID Tag } \\
- & \text { FRID reader }\end{array}$ & 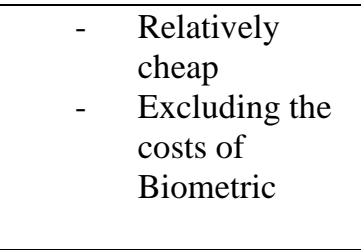 & $\begin{array}{ll}- & \text { Cheap } \\
- & \text { Excluding } \\
& \text { FRID- } \\
& \text { related costs }\end{array}$ & $\begin{array}{l}\text { cost more than } \\
\text { standalone systems due } \\
\text { costs of additional } \\
\text { technology. }\end{array}$ \\
\hline $\begin{array}{cl}\text { Privacy/Security attacks } \\
\text { - } & \text { Cloning attacks } \\
\text { - } & \text { Tag impersonation } \\
\text { - } & \text { Spoofing attack } \\
\text { - } & \text { Hacking } \\
\text { - } & \text { Tag/Reader/server } \\
& \text { impersonation } \\
\text { - } & \text { Theft attack } \\
\text { - } & \text { Malware attack }\end{array}$ & $\begin{array}{l}\text { Strongly vulnerable } \\
\text { to alltypes of attacks } \\
\text { due to lack of } \\
\text { standardization }\end{array}$ & $\begin{array}{l}\text { Vulnerable to theft } \\
\text { and database } \\
\text { attacks }\end{array}$ & 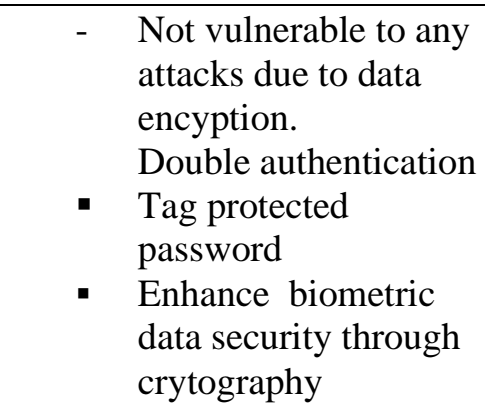 \\
\hline IoT/e-mail Service & None & None & $\begin{array}{l}\text { Enhance with Wi-Fi module, } \\
\text { e-mail service through GSM } \\
\text { module }\end{array}$ \\
\hline Database Template & Not encrypted & Not encrypted & Encrypted \\
\hline
\end{tabular}




\begin{tabular}{|l|l|l|l|}
\hline $\begin{array}{l}\text { Biometric metric } \\
\text { (FRR, FAR) }\end{array}$ & None & high & $\begin{array}{l}\text { Lower (Over 80\% of } \\
\text { legitimate users are accepted.) }\end{array}$ \\
\hline User mode of Access & FRID tag & Fingerprint & FRID Tag, Fingerprint \\
\hline Communication & Wireless technology & Biometric & $\begin{array}{l}\text { Wi-Fi, IoT, SMS, biometric, } \\
\text { wireless technolgy }\end{array}$ \\
\hline
\end{tabular}

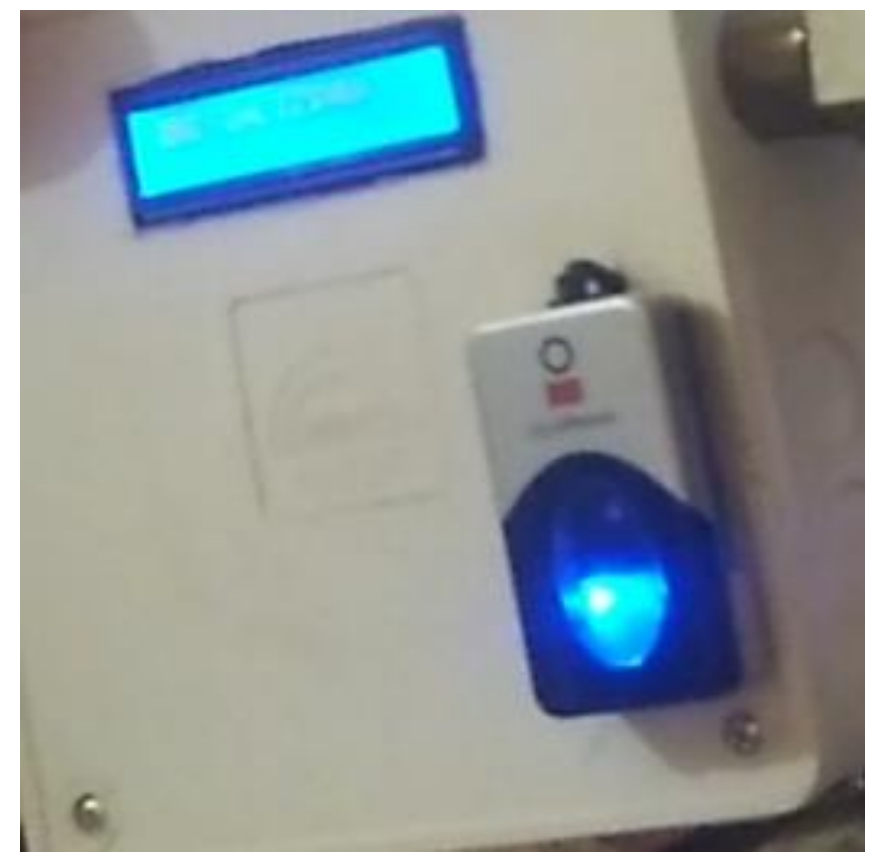

Figure 12. Proposed RFID and Biometric based Library Management System

\section{CONCLUSION}

This paper presents a smart book search and a library management system which is based on RFID technology and the biometric recognition system to improve the existing library management system in terms of efficiency and modus operandi. The design of the database was developed with MYSQL an opensource relational management system and was also programmed with a Java programming language to improve the book searching rate, free more staff and to enhance other library services. The proposed design combined radio frequency identification (RFID) and Biometric technology to enhance user processing time, improve the user's service, curtail the book theft, to ease updating of new books and further increase the biometric security of the system against an imposter.

Furthermore, the integration of biometric, RFID and IoT technologies drastically enhance fast and an intelligent issuing, returning books and eradicate the manual work that should to be done previously by the staff. The system performance was compared with the manual method in terms of book positioning function, false rejection rate, false acceptance rate, counting efficiency, average time spent in booking searching and the result show that the proposed outperforms the conventional (manual) library system. For improved efficiency, the proposed design is integrated with an SMS and email alert system to notify the user with the date of issue, return due date and it's related fine. Finally, a web-application based on internet of things (IoT) was incorporated into the system to provide the user with unrestricted access to online library facilities with a personal computer or mobile devices. The proposed design thus allows the user to access books and course materials from a remote location in an authenticated and secured manner. 


\section{ACKNOWLEDGMENTS}

The authors would like to appreciate various authors whose literature provided detailed information that assisted in the preparation of this manuscript. Also, the authors would love to acknowledge the extensive research work done by Late Engr. Oluwadamilola Kehinde Oyetola on the smart library management system adopted in this work. Various comments and suggestion received from the co-researchers that have added value to this work are also appreciated.

\section{CONFLICTS OF INTEREST}

No conflict of interest was declared by the authors.

\section{REFERENCES}

[1] UN, "2020 policy brief covid-19 and education", Education during COVID-19 and beyond, Retrieved from https://www.un.org/development/desa/dspd/wpcontent/uploads/sites/22/2020/08/sg-policy-brief-covid-19-and- education.pdf, Accessed date: 29.05 .2020

[2] Roberts, C. M., "Radio frequency identification", Computers and Security, 5 (25): 18-26, (2006).

[3] Avery, W. S., Li-Shiang, T., Kateeb, I. A., Burton, L.,"Solutions for RFID Smart Tagged Card Security Vulnerabilities", AASRI Procedia, 4: 282-287, (2013).

[4] Ojha, N., "Radio Frequency Identification Technology in Library: Advantages and Issues", Proceedings of the 2. International Conference on Inventive Systems and Control, Coimbatore, India, (2018).

[5] Saparkhojayev, N., "RFID - based Staff Control System in Kazakhstan ", Proceedings of the 3. International Conference on Science and Engineering in Mathematics, Chemistry and Physics, Bali, Indonesia, (2015).

[6] Haiming C., Ling, H., He, X., Yifan, H., "Design and implementation of library books search management system using RFID technology", Proceedings of the 8. International Conference on Intelligent Networking and Collaborative Systems, Ostrava, Czech Republic, (2016).

[7] Amit, M., "RFID Based Library Management System", International Journal of Emerging Technologies and Innovative Research, 4 (6): 279-282, (2017).

[8] Duroc, Y., Tedjini,S., "Comptes Rendus Physique RFID : A key technology for Humanity”, Comptes Rendus Physique, 19(1-2), 64-71, (2018).

[9] Renold, A. P., Joshi, R. R., “An Internet Based RFID Library Management System”, proceedings of the 15. IEEE Conference on Information and Communication Technologies, Tamil Nadu, India, (2013).

[10] R-moreno, M. D., Castaño, B., Barrero, D. F., Hellín, A. M., "Efficient Services Management in Libraries using AI and Wireless techniques", Expert Systems with Applications, 41: 7904-7913, (2014).

[11] Dwivedi,Y. K., Kaur, K., Williams, M. D., Williams, J.,“RFID systems in libraries : An empirical examination of factors affecting system use and user satisfaction", International Journal of Information Management, 33(2): 367-377, (2013).

[12] Daim,T. J., Mohd, R., Lee, A., “3D RFID-Based Library Search System Application Development”, 
Proceedings of the 15. IEEE Student Conference on Research and Development, Putrajaya, Malaysia, (2017).

[13] Gibb, F., Thornley, C., Ferguson, S., Weckert, J., "The application of RFIDs in libraries : an assessment of technological , Management and Professional İssues", International Journal of Information Management, 31(3): 244-251, (2011).

[14] Zhang, J. F., "The University Library Management System Based on Radio Frequency Identification", Proceedings of the 10. International Congress on Image and Signal Processing, BioMedical Engineering and Informatics, Shanghai, China, (2017).

[15] Oyetola, O. K., Okubanjo, A. A., Osifeko, M. O., Alao, P. O.,"Secured biometrics-crypto authentication system over computer network", FUW Trends in Science and Technology Journal, 5(1): 134-140, (2020).

[16] Oyetola, O. K., Okubanjo A. A.,, Osifeko, M. O., Sanusi, O. I., Abolade, O. R., "An improved authentication system using hybrid of biometrics and cryptography", Proceedings of the 10. IEEE International Conference on Electro-Technology for National Development, Owerri, Nigeria, (2018).

[17] Ennaama, F., Benhida, K., Boulahoual, A., "Face recognition of face images with hidden parts using gabor wavelets and PCA", Periodicals of Engineering and Natural Sciences, 6(2): 316-322, (2018).

[18] Taher, H. B., Hashim, K. M., Oudah, A. Y., "Adaptive hybrid technique for face recognition", Periodicals Journal of Engineering and Natural Sciences, 7(2): 818-823, (2019).

[19] Paul, H. C., Elango, S., Monday, D. N., "Biometric and rfid technology fussion : a security and monitoring measures to enhance", International Journal of Information System and Engineering, 4(1): 1-8, (2016).

[20] Ancy, M. E., "RFID based attendance management system with face", International Journal of Advances in Electronics and Computer Science, 5(6): 19-23, (2018).

[21] Kelvin, U., Ekwe, N., Agwu, O., Chinonso, O.,"Radio Frequency Identification Based Attendance System with Short Message Service ( SMS ) Backup", Journal of Computer Engineering, 21(2): 18, (2019).

[22] Ramesh, M.Y., "Biometric Recognition: A New Approach for Library Patron Authentication", International Journal of Library Science, 1(5): 72-74, (2012).

[23] Huang, Q., Huang, H., "Intelligent Electronic Management of Library by Radio Frequency Identification Technology", Data Science Jounal, 18: 1-8, (2019).

[24] Supriya, C. K., Bhuyar, D. L., "Design and Implementation of Book Security", International Journal of Innovative Research in Computer and Communication Engineering, 4(8): 15170-15176, (2016).

[25] Olaniyi, O. M., Nuhu, B. K., Salau, S. A., Musa, A. B., Oparaocha, P. C., "Securıng digitized library circulatory system", Nigerian Journal of Technolpogy, 35(2): 598-607, (2016).

[26] Srujana, C., Murthy, B. R., Alam, K. T., Sunitha, U., Mahammad, D. V., Thimmaiah, P., "Development of RFID Based Library Management System Using MATLAB", American Journal of Engineering Research, 5(4): 480-483, (2013).

[27] Mohammed, A ., Wan, M. N., Muhamad, S ., "Study on RFID Based Book Tracking and Library Information System", Proceedings of the 15. IEEE Colloquium on Signal Processing and its 
Applications, Penang, Malaysia, (2019).

[28] Muthuselvi, R., "Asset tracking and management system for library using active radio frequency identification ( RFID )", Biomedical Research, 20: 128-133, (2016).

[29] Dong-Ying, L., Xie, S., Chen, R., "Design of Internet of Things System for Library Materials Management Using UHF RFID", proceedings of the 7. IEEE International Conference on RFID Technology and Applications, Foshan, China, (2016).

[30] Pujari, T. S., "Design of Intelligent and Robotic Library System", Proceedings of the 2. IEEE International Conference On Recent Trends in Electronics Information and Communication Technology, Bangalore, India, (2017).

[31] Oyetola, O. K., Okubanjo, A. A., Olaluwoye, O. O., "A Secure Students ' Attendance Monitoring System", Amity Journal of Engeneering and Technology, 2(2): 1-7, (2017).

[32] Jothilakshmi, S., Gudivada,V.N., "Large Scale Data Enabled Evolution of Spoken Language Research and Applications", in Handbook of Statistics, 35(1): 301-340, Elsevier B.V., (2016).

[33] Furui, S., "Speaker Recognition in Smart Environments", in Human-Centric Interfaces for Ambient Intelligence, (1): 163-184, Elsevier, (2010).

[34] Traore, I., Alshahrani, M., Obaidat, M.S., "State of the art and perspectives on traditional and emerging biometrics: A survey", Security and Privacy, 1(6): e44, (2018).

[35] Rui, Z., Yan, Z., "A Survey on Biometric Authentication: Toward Secure and Privacy-Preserving Identification”, IEEE Access, 7(1): 5994-6009,( 2019). 